\title{
Effect of Selenium Fertilization and Methyl Jasmonate Treatment on Glucosinolate Accumulation in Broccoli Florets
}

\author{
Hyoung Seok Kim and John A. Juvik ${ }^{1}$ \\ Department of Crop Sciences, 1201 W. Gregory Avenue, University of Illinois, Urbana, IL 61801
}

\begin{abstract}
Additional Index words. Brassica oleracea ssp. italica, jasmonic acid, genotype, health promotion
Abstract. Broccoli (Brassica oleracea ssp. italica) is a rich source of glucosinolates (GSs), phytochemicals that are hydrolyzed into isothiocyanates with known human anticarcinogenic bioactivity. Increasing dietary intake of the element selenium (Se) can also reduce the risk of cancer. Previous research reported that Se fertilization at high concentrations reduces the concentration of GSs in brassicaceous plants. This research was conducted to determine the effect of Se fertilization on accumulation of different types of GSs in broccoli floret tissues in five genotypes. Methyl jasmonate (MeJA), an elicitor known to stimulate biosynthesis of indolyl GSs, was used to analyze changes in biosynthetic capability of indolyl GSs in broccoli floret tissue under Se-enriched conditions. Five broccoli genotypes were subjected to root fertilization with low and high levels of $\mathrm{Na}_{2} \mathrm{SeO}_{4}$ solutions ( 0.17 and $\left.5.2 \mathrm{~mm}\right)$, MeJA sprays to aerial portions of the plants $(250 \mu \mathrm{M})$, and the combined treatment of $5.2 \mathrm{mM}$ Se with $250 \mu \mathrm{M} \mathrm{MeJA}$, respectively. The effect of Se fertilization on GS accumulation varied among genotypes and the level of Se fertilization. Variation in the level of Se fertilization resulted in a dose-dependent decrease in glucoraphanin concentrations with no significant effect on indolyl GS accumulation in broccoli florets across the five genotypes. MeJA treatment increased indolyl and aromatic GS accumulation in floret tissues. MeJA-mediated increases in these GSs were inhibited in the high Se fertilization treatment, but the increase in neoglucobrassicin concentrations was less affected than other GSs in florets across the five genotypes. An experiment conducted with 6-week-old broccoli plants under the high Se treatment demonstrated greater accumulation of Se with depressed accumulation of sulfur and complete inhibition of MeJAmediated indolyl GS accumulation compared with those changes in florets of mature broccoli plants. These results suggest that GS accumulation under Se fertilization may be influenced by not only the level of Se fertilization, but also the differences in sizes of available pools of resources (sulfur and sulfur-containing amino acids) required for GS biosynthesis and accumulation in broccoli plants. Partitioning of the variance indicated that the existence of substantial variability in GS concentrations was primarily attributed to differences in genotype response across different treatments. Results suggest that cultivar selection and breeding of broccoli can be used to develop broccoli germplasm with enhanced capacity for Se uptake and stability of GS biosynthesis with varying Se fertilization.
\end{abstract}

Selenium, a naturally occurring element found in many soils, is an essential micronutrient for animals and humans (Rayman, 2004; White and Broadley, 2005). Dietary supplementation of 200 $\mu \mathrm{g}$ Se per day has been demonstrated to be associated with reduced risk of certain cancers in humans (Clark et al., 1996), and consumption of Se-enriched broccoli also showed enhanced protection against colon and mammary cancer in laboratory animals compared with control broccoli alone (Davis et al., 2002; Finley et al., 2000, 2001). Selenium cannot be added to food directly, because $\mathrm{Se}$ is not on the list of additives generally recognized as safe by the U.S. Food and Drug Administration (Finley et al., 2005). Selenium must be enriched naturally through fertilization or crop production on appropriate soils that lead to the accumulation and concentration of Se in food sources.

Brassica vegetables have received considerable attention as a result of their chemopreventive properties that are mainly attributed to GS degradation products. Among Brassica vegetables, broccoli is a rich source of GSs, phytochemicals that are hydrolyzed into isothiocyanates with known human anticarcinogenic bioactivity (Talalay and Fahey, 2001). Broccoli has been considered as a candidate to supply both Se and GSs to the human diet (Finley et al., 2005; Keck and Finley, 2006). Selenium fertilization successfully increased Se accumulation

Received for publication 28 Mar. 2011. Accepted for publication 9 June 2011. ${ }^{1}$ Corresponding author. E-mail: juvik@illinois.edu. in broccoli (Pedrero et al., 2008; Robbins et al., 2005; Sugihara et al., 2004), but high concentration of Se fertilization resulted in a decrease in GS concentrations, especially in aliphatic GSs, including glucoraphanin, the parent GS of the isothiocyanate sulforaphane in broccoli florets (Robbins et al., 2005). Similar effects of Se fertilization were reported in leaf tissues of rapidcycling B. oleracea (Charron et al., 2001; Toler et al., 2007). Previous research analyzing the effect of Se fertilization on GS accumulation has shown different responses between the shoot tissues of rapid-cycling $B$. oleracea and floret tissues of broccoli (Charron et al., 2001; Robbins et al., 2005). Greater reduction in total GSs ( $\approx 67 \%$ reduction) was found in shoot tissues of rapid-cycling $B$. oleracea compared with floret tissues of broccoli ( $\approx 27 \%$ reduction in total GSs) after Se fertilization, whereas the respective tissues accumulated comparable Se levels.

Although previous research reported the effect of Se fertilization on GS accumulation in broccoli, it was tested in only two broccoli genotypes (Robbins et al., 2005). We have investigated changes in Se and GS concentrations in five different broccoli cultivars after Se fertilization, MeJA treatments, or a combination of these treatments. Methyl jasmonate, a volatile methylester of jasmonic acid, can elicit accumulation of GS in Brassica species, specifically of indolyl GSs (Bodnaryk, 1994; van Dam et al., 2003). Treatment of exogeneous MeJA increased the amount of indolyl GSs through the highly induced expression of the 
corresponding Trp-metabolizing genes CYP79B2 and $C Y P 79 B 3$ catalyzing the conversion of tryptophan to indole3 -acetaldoxime and conversion of aldoximes to thiohydroximic acids, respectively (reviewed in Halkier and Gershenzon, 2006). Increasing biosynthesis of indolyl GSs derived by MeJA treatment is particularly interesting as a result of their potential to not only provide information on synthetic capability of GSs in broccoli plants, but also to improve the health-promoting bioactivity of broccoli through the increased levels of indolyl GSs (Liu et al., 2009).

Identification or development of genotypes with enhanced and stable levels of Se and GSs is particularly important to provide a value-added inducement for increased broccoli consumption with superior health promotion effects. The feasibility of Se fertilization and MeJA treatment for improvement in Se and GS concentrations was evaluated by partitioning the phenotypic variability into its component sources [genotype, treatment and genotype $\times$ treatment $(\mathrm{G} \times \mathrm{T})$ interaction]. If a high proportion of the phenotypic variance for a specific trait is described by treatment effects, the corresponding treatment approach may be feasible to improve trait performance. If the dominant proportion of phenotypic variance is the result of genotypic differences, this indicates the feasibility of genetic manipulation to improve GS upregulation and Se uptake. The proportion of phenotypic variance described by $\mathrm{G} \times \mathrm{T}$ interaction can be used to estimate the breeding potential to create genotypes optimized for specific treatments.

The aim of this study was to analyze the effect of Se fertilization on GS accumulation in broccoli florets. Genotypedependent Se and GSs accumulations under the Se fertilization conditions were analyzed in floret tissues of five broccoli genotypes. Through treatment with MeJA with or without Se fertilization, we tested whether Se-enriched conditions can differentially inhibit the MeJA-mediated accumulation of indolyl GSs in different tissue types, basal leaves of 6-week-old broccoli plants, and floret tissues of mature plants. Sulfur and Se concentrations were determined in the same tissues to analyze relationship between sulfur status and MeJA-mediated GS accumulation.

\section{Materials and Methods}

Plant materials. Broccoli seeds of two doubled haploid genotypes, VI-158 and SU-003 (courtesy of M. Farnham, USDA, Charleston, SC), and three commercial hybrids ['Brigidier' (Asgrow Seed Co., Kalamazoo, MI) and 'Sultan' and 'Green Magic' (Sakata Seed America, Salinas, CA)] were germinated in small pots filled with Sunshine ${ }^{\circledR}$ LC1 professional soil mix (Sun Grow Horticulture, Bellevue, WA). Four-week-old broccoli plants were transplanted into 22.8-cm-diameter pots and grown in a greenhouse at the University of Illinois at ChampaignUrbana under a $25 / 15^{\circ} \mathrm{C}$ and $14 / 10$-h day/night temperature regime and with supplemental light. Three weeks after transplanting, plants were fertilized with a solution of $20 \mathrm{~N}-8.8 \mathrm{P}-$ $16.6 \mathrm{~K}$ diluted to $125 \mathrm{ppm}$ with water twice per week. The experimental design was a $5 \times 5$ factorial in a completely randomized design with five genotypes and five treatments including control. There were three replicates for each factor combination.

For the 6-week-old broccoli plant materials, 4-week-old plants of 'Green Magic' were transplanted into 5-cm-diameter pots and grown for 2 weeks under the same greenhouse conditions as described previously. The experimental design was a randomized complete block with three replicates of three young plants combined.

SELENIUM FERTILIZATION AND METHYL JASMONATE TREATMENTS. In the first experiment, mature broccoli plants of five genotypes were subjected to root fertilization with low and high levels of $\mathrm{Na}_{2} \mathrm{SeO}_{4}$ solutions $(0.17$ and $5.2 \mathrm{~mm})$, MeJA sprays to aerial portions of the plants $(250 \mu \mathrm{M})$, and the combined treatment of $5.2 \mathrm{~mm}$ Se with $250 \mu \mathrm{M}$ MeJA, respectively. Two different levels of Se fertilization were applied as soil drenches to the broccoli plants at the floral initiation stage as described by Finley et al. (2000). Briefly, when plants initiated floral primordia, $10 \mathrm{~mL}$ of 0.17 and $5.2 \mathrm{~mm} \mathrm{Na}_{2} \mathrm{SeO}_{4}$ solution were applied to each plant container twice per week until plants formed visible heads, and then $20 \mathrm{~mL}$ of each solution was added twice per week until heads were fully formed and at market harvest maturity. A total of $\approx 100 \mathrm{~mL}$ of the Se solutions was supplied to individual broccoli plants before harvest of mature broccoli florets. All aerial parts of broccoli plants, including the floret, stem, and leaf tissues, were sprayed with $250 \mu \mathrm{M}$ MeJA (SigmaAldrich, St. Louis, MO) containing 0.1\% Triton X-100 (SigmaAldrich) until plant surfaces were fully saturated with the MeJA solution $4 \mathrm{~d}$ before tissue harvest. Each plant was sprayed with $\approx 80 \mathrm{~mL}$ of the MeJA solution using a hand sprayer on the same day as the Se treatment. Control plants were sprayed with water containing $0.1 \%$ Triton X-100. Plants were spray-treated in isolation and completely dried before being placed back onto greenhouse benches. Combination treatments of Se and MeJA were conducted by spraying $250 \mu \mathrm{M}$ MeJA solution on plants fertilized with the high level of $\mathrm{Se}\left(5.2 \mathrm{~mm} \mathrm{Na}_{2} \mathrm{SeO}_{4}\right.$ solution). Broccoli heads were harvested just below the lowest branch of the immature inflorescence. Equal subsamples of the edible portions of the three harvested heads from each replicate and treatment were combined, frozen in liquid nitrogen, lyophilized, ground into a powder, and stored at $-20{ }^{\circ} \mathrm{C}$ until analyzed.

In the second experiment, $5 \mathrm{~mL}$ of $5.2 \mathrm{~mm} \mathrm{Na}_{2} \mathrm{SeO}_{4}$ solution was applied to each 4-week-old plant of 'Green Magic' three times per week for 2 weeks. Two hundred fifty $\mu \mathrm{M}$ MeJA or control solutions were sprayed onto all aerial parts of the 6-week-old plants $4 \mathrm{~d}$ before tissue harvest. Apical (second or third leaf node from the apical meristem) and basal (fourth to seventh leaf node) leaves were harvested and combined in each of three replicates and frozen in liquid nitrogen, lyophilized, ground into powder, and stored at $-20{ }^{\circ} \mathrm{C}$ until analysis.

Glucosinolate anAlysis. Glucosinolates in lyophilized tissue were extracted and analyzed by high-performance liquid chromatography (HPLC) using a reverse phase C18 column as described by Brown et al. (2002) with some modifications. DesulfoGSs were separated on a HPLC system (GP40 gradient pump and AD20 ultraviolet absorbance detector; Dionex, Sunnyvale, CA) consisting of a variable ultraviolet detector set at $229 \mathrm{~nm}$ wavelength. DesulfoGSs were eluted off the column in 45 min with a linear gradient of $0 \%$ to $20 \%$ acetonitrile in water at a flow rate of $1.0 \mathrm{~mL} \cdot \mathrm{min}^{-1}$. The type and amount of GSs in each sample were calculated in comparison with certified glucosinolate levels in a standard rapeseed reference material (Linsinger et al., 2001). Glucosinolates were quantified with benzylglucosinolate (POS Pilot Plant Corp., Saskatoon, Saskatechewan, Canada) as an internal standard using ultraviolet response factors for different types of GSs determined by Wathelet et al. (2001).

Determination OF SELENIUM AND SULFUR CONCENTRATIONS. Analysis of tissue Se and sulfur concentrations was performed by the Division of Agriculture and Natural Resources Analytical 
Laboratory at the University of California, Davis. Total Se was analyzed by nitric acid-perchloric acid-sulfuric acid digestion and determination by a vapor generation inductively coupled plasma emission spectrometer (Tracy and Moeller, 1990). Total sulfur content was determined through a nitric acid-hydrogen peroxide microwave digestion and determination by inductively coupled plasma atomic emission spectrometry (Sah and Miller, 1992).

Statistical analysis. Glucosinolate, total Se, and sulfur concentrations obtained from the tissue samples of broccoli plants treated with Se fertilizer, MeJA, or a combination of Se fertilizer and MeJA and controls were analyzed by the GLM procedure and Fisher's least significant difference tests using SAS (Version 8.0; SAS Institute, Cary, NC).

Analysis of variance using PROC MIXED (SAS Version 8.0) was performed on the data based on the linear model:

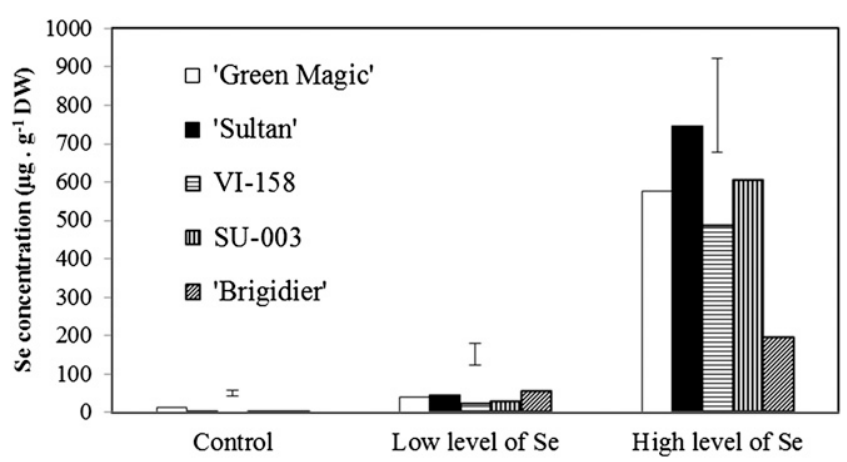

Fig. 1. Variation in selenium (Se) concentrations $\left(\mu \mathrm{g} \cdot \mathrm{g}^{-1}\right.$ dry weight) among five broccoli genotypes in control plants and plants treated with two different levels of Se fertilizer $\left(0.17\right.$ or $5.2 \mathrm{~mm}$ of $\left.\mathrm{Na}_{2} \mathrm{SeO}_{4}\right)$. Vertical bars indicate least significant difference values $(P=0.05)$ for comparison across genotypes. $x_{i j k}=\mu+\alpha_{i}+\beta_{j}+(\alpha \beta)_{i j}+\tau_{k(j)}+e_{i j k}$, where $x_{i j k}$ is the kth replicate of the phenotypic value of the ith genotype in treatment $j, \mu$ is the overall mean, $\alpha_{\mathrm{i}}$ is the fixed effect of genotype $\mathrm{i}, \beta_{\mathrm{j}}$ is the random effect of treatment $\mathrm{j},(\alpha \beta)_{\mathrm{ij}}$ is the random interaction effect of genotype $\mathrm{i}$ in treatment $\mathrm{j}, \tau_{\mathrm{k}(\mathrm{j})}$ is the nested effect of the kth block within the $\mathrm{jth}$ treatment, and $\mathrm{e}_{\mathrm{ijk}}$ is the experimental error associated with $\mathrm{x}_{\mathrm{ijk}}$. F tests at $P<0.05$ were used to determine the significance of the individual variance components.

\section{Results and Discussion}

Selenium fertilization. Two different levels of Se fertilization resulted in a dose-dependent increase of Se concentrations in floret tissues of five broccoli genotypes (Fig. 1). The overall increase of Se concentrations averaged across the five genotypes ranged from 3.0 (control) to $36.0 \mu \mathrm{g} \cdot \mathrm{g}^{-1}$ dry weight of tissue (low level of Se fertilization) and to $520 \mu \mathrm{g} \cdot \mathrm{g}^{-1}$ (high level of Se fertilization). Selenium accumulation in floret tissues under the high level of Se fertilization was significantly different among the genotypes (Fig. 1). 'Brigidier' had a lower level of Se in floret tissues than the other genotypes. Variation in Se accumulation observed among the five broccoli genotypes suggests that selection and breeding can be performed to develop broccoli germplasm with modified capacity for Se acquisition and accumulation under the high level of $\mathrm{Se}$ fertilization.

The effect of two different levels of Se fertilization on GS accumulation in floret tissues is presented in Table 1. The high level of Se fertilization decreased the concentration of glucoraphanin and total aliphatic GSs in two of five genotypes. No significant reduction in glucoraphanin or total aliphatic GS concentrations was observed in 'Brigidier', which showed relatively less Se accumulation compared with other genotypes

Table 1. Effect of different levels of selenium fertilization on glucosinolate (GS) concentration in floret tissues of five broccoli genotypes ( $\mathrm{n}=3$ ) .

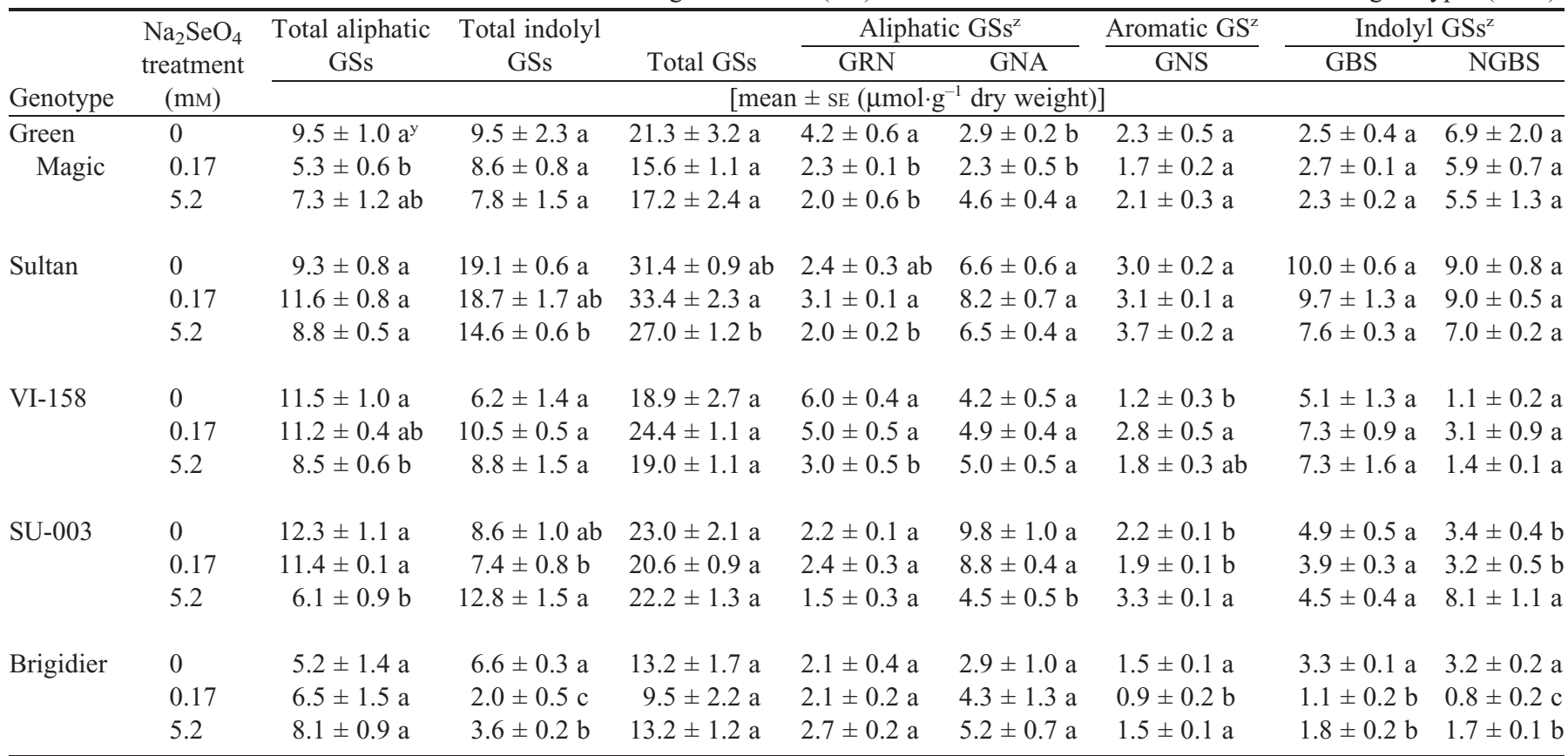

$\overline{{ }^{\mathrm{z}} \mathrm{GRN}}=$ glucoraphanin; GNA $=$ gluconapin; GNS = gluconasturtiin; GBS = glucobrassicin; NGBS = neoglucobrassicin. The total aliphatic and indolyl GS concentrations also include the concentration of glucoiberin and progoitrin and 4-methoxyglucobrassicin, respectively.

${ }^{\mathrm{y}}$ Means with a different letter in each column for each genotype are significantly different at $P<0.05$, using Fisher's least significant difference analysis. 
under high Se fertilization (Table 1). Indolyl and aromatic GSs did not show a consistent response to Se fertilizations across the genotypes suggesting that there is little or no influence of Se fertilization on accumulation of these GSs in florets. Higher concentrations of glucoraphanin were observed in control treatments of VI-158 and 'Green Magic', and these genotypes exhibited a more dramatic reduction in glucoraphanin concentrations $(50 \%$ and $53 \%$ reduction, respectively) in plants treated with the high level of Se fertilization.

Methyl Jasmonate inCREASES INdolyl GLUCOSINOLATE ACCUMULATION. The concentrations of indolyl and aromatic GSs significantly increased in florets of three of five genotypes after MeJA treatment, and these increases made the total GS concentrations greater than in the untreated plants in these genotypes (Table 2). Neoglucobrassicin concentrations in 'Green Magic' and SU-003 showed the most dramatic increases (ranging from 2.8- to 4.3-fold over controls) with 'Sultan' having the highest concentrations of this compound $\left(18.4 \mu \mathrm{mol} \cdot \mathrm{g}^{-1}\right.$ dry weight $)$ with MeJA treatment. The combined treatment of MeJA with the high level of Se fertilization decreased total aliphatic GS concentrations in three of five genotypes in comparison with high Se only (Table 1), suggesting a competitive interaction between Se accumulation and aliphatic GS biosynthesis, although this interaction appears to be genotype-dependent.
VARIATION IN GLUCOSINOLATE CONCENTRATIONS ACROSS THE FIVE BROCCOLI GENOTYPES. Table 3 shows that the low level of Se fertilization did not influence concentrations of all classes of GSs significantly, whereas the high level of Se treatment decreased concentrations of glucoraphanin and total aliphatic GSs by $34 \%$ and $19 \%$, respectively. Concentrations of two indolyl GSs, glucobrassicin, and neoglucobrassicin, were not significantly changed by the different levels of Se fertilization in florets across the five genotypes. This result is consistent with a previous report in which two different levels of Se fertilization resulted in a dose-dependent decrease in aliphatic GS concentrations with no significant effect on indolyl GS accumulation in the florets of 'Majestic' (Robbins et al., 2005).

The sensitivity of aliphatic GSs, specifically glucoraphanin, to Se fertilization may be a consequence of reduction in plant cysteine and methionine biosynthesis caused by the competitive biosynthesis of Se-cysteine and Se-methionine. GSs contain at least two sulfur atoms, one originating from cysteine and the other from phosphoadenosine phosphosulfate (reviewed in Rausch and Wachter, 2005). Methionine-derived aliphatic GSs contain an additional reduced sulfur atom. It can be assumed that methioninederived aliphatic GS biosynthesis may be more strongly sulfur or sulfur-containing amino acid-dependent compared with indolyl glucosinolates derived from tryptophan (Schonhof et al., 2006).

Table 2. Effect of methyl jasmonate (MeJA) spray and combination treatment of MeJA with high levels of selenium (Se) fertilization on glucosinolate (GS) concentration in floret tissues of five broccoli genotypes $(n=3)$.

\begin{tabular}{|c|c|c|c|c|c|c|c|c|c|}
\hline \multirow[b]{2}{*}{ Genotype } & \multirow[b]{2}{*}{ Treatment ${ }^{\mathrm{z}}$} & $\begin{array}{c}\text { Total } \\
\text { aliphatic } \\
\text { GSs }\end{array}$ & $\begin{array}{c}\text { Total } \\
\text { indolyl } \\
\text { GSs }\end{array}$ & Total GSs & \multicolumn{2}{|c|}{ Aliphatic $\mathrm{GSs}^{\mathrm{y}}$} & $\frac{\text { Aromatic } \mathrm{GS}^{\mathrm{y}}}{\mathrm{GNS}}$ & \multicolumn{2}{|c|}{ Indolyl GSs ${ }^{\mathrm{y}}$} \\
\hline & & \multicolumn{8}{|c|}{$\left[\right.$ mean \pm SE $\left(\mu \mathrm{mol} \cdot \mathrm{g}^{-1}\right.$ dry weight $\left.)\right]$} \\
\hline \multirow[t]{2}{*}{ Magic } & MeJA & $10.0 \pm 2.2 \mathrm{a}$ & $20.1 \pm 1.1 \mathrm{a}$ & $34.0 \pm 2.0 \mathrm{a}$ & $5.4 \pm 1.4 \mathrm{a}$ & $2.2 \pm 0.3 \mathrm{a}$ & $3.9 \pm 0.4 \mathrm{a}$ & $2.9 \pm 0.3 \mathrm{a}$ & $17.1 \pm 1.0 \mathrm{a}$ \\
\hline & $\begin{array}{l}\mathrm{MeJA}+ \\
\quad 5.2 \mathrm{~mm} \mathrm{Se}\end{array}$ & $6.5 \pm 0.3 \mathrm{a}$ & $21.3 \pm 0.4 \mathrm{a}$ & $30.7 \pm 0.2 \mathrm{a}$ & $2.1 \pm 0.2 \mathrm{a}$ & $3.3 \pm 0.5 \mathrm{a}$ & $3.0 \pm 0.04 \mathrm{ab}$ & $1.7 \pm 0.03 \mathrm{~b}$ & $19.4 \pm 0.4 \mathrm{a}$ \\
\hline \multirow[t]{3}{*}{ Sultan } & Control & $9.3 \pm 0.8 \mathrm{a}$ & $19.1 \pm 0.6 \mathrm{~b}$ & $31.4 \pm 0.9 \mathrm{~b}$ & $2.4 \pm 0.3 \mathrm{a}$ & $6.6 \pm 0.6 \mathrm{a}$ & $3.0 \pm 0.2 \mathrm{c}$ & $10.0 \pm 0.6 \mathrm{ab}$ & $9.0 \pm 0.8 b$ \\
\hline & MeJA & $10.3 \pm 0.8 \mathrm{a}$ & $29.4 \pm 1.6 \mathrm{a}$ & $44.6 \pm 2.0 \mathrm{a}$ & $2.6 \pm 0.03 \mathrm{a}$ & $7.4 \pm 0.8 \mathrm{a}$ & $4.9 \pm 0.3 \mathrm{ab}$ & $10.6 \pm 0.7 \mathrm{a}$ & $18.4 \pm 0.9 \mathrm{a}$ \\
\hline & $\begin{array}{l}\mathrm{MeJA}+ \\
\quad 5.2 \mathrm{~mm} \mathrm{Se}\end{array}$ & $8.4 \pm 0.8 \mathrm{a}$ & $22.9 \pm 1.6 \mathrm{~b}$ & $35.7 \pm 1.3 b$ & $1.7 \pm 0.02 \mathrm{a}$ & $6.4 \pm 0.8 \mathrm{a}$ & $4.4 \pm 0.4 \mathrm{~b}$ & $5.9 \pm 0.4 \mathrm{c}$ & $16.9 \pm 2.0 \mathrm{a}$ \\
\hline VI-158 & Control & $11.5 \pm 1.0 \mathrm{a}$ & $6.2 \pm 1.4 \mathrm{~b}$ & $18.9 \pm 2.7 \mathrm{~b}$ & $6.0 \pm 0.4 \mathrm{a}$ & $4.2 \pm 0.5 \mathrm{a}$ & $1.2 \pm 0.3 \mathrm{~b}$ & $5.1 \pm 1.3 \mathrm{~b}$ & $1.1 \pm 0.2 \mathrm{~b}$ \\
\hline \multirow[t]{3}{*}{ SU-003 } & Control & $12.3 \pm 1.1 \mathrm{a}$ & $8.6 \pm 1.0 \mathrm{~b}$ & $23.0 \pm 2.1 \mathrm{ab}$ & $2.2 \pm 0.1 \mathrm{a}$ & $9.8 \pm 1.0 \mathrm{a}$ & $2.2 \pm 0.1 \mathrm{ab}$ & $4.9 \pm 0.5 \mathrm{a}$ & $3.4 \pm 0.4 b$ \\
\hline & MeJA & $9.8 \pm 0.7 \mathrm{a}$ & $21.1 \pm 5.2 \mathrm{a}$ & $34.4 \pm 6.3 \mathrm{a}$ & $2.4 \pm 0.4 \mathrm{a}$ & $7.1 \pm 0.9 \mathrm{a}$ & $3.5 \pm 0.6 \mathrm{a}$ & $5.8 \pm 1.0 \mathrm{a}$ & $14.7 \pm 4.3 \mathrm{a}$ \\
\hline & $\begin{array}{l}\mathrm{MeJA}+ \\
\quad 5.2 \mathrm{~mm} \mathrm{Se}\end{array}$ & $1.2 \pm 0.2 \mathrm{~b}$ & $5.9 \pm 1.2 \mathrm{~b}$ & $8.1 \pm 1.5 b$ & $0.8 \pm 0.2 \mathrm{~b}$ & $0.3 \pm 0.1 \mathrm{~b}$ & $1.0 \pm 0.2 \mathrm{~b}$ & $1.8 \pm 0.3 \mathrm{~b}$ & $4.2 \pm 0.9 \mathrm{~b}$ \\
\hline \multirow[t]{3}{*}{ Brigidier } & Control & $5.2 \pm 1.4 \mathrm{ab}$ & $6.6 \pm 0.3 \mathrm{a}$ & $13.2 \pm 1.7 \mathrm{a}$ & $2.1 \pm 0.4 \mathrm{a}$ & $2.9 \pm 1.0 \mathrm{~b}$ & $1.5 \pm 0.1 \mathrm{a}$ & $3.3 \pm 0.1 \mathrm{a}$ & $3.2 \pm 0.2 \mathrm{a}$ \\
\hline & MeJA & $4.3 \pm 0.9 \mathrm{~b}$ & $10.4 \pm 2.6 \mathrm{a}$ & $16.5 \pm 4.0 \mathrm{a}$ & $2.2 \pm 0.3 \mathrm{a}$ & $1.9 \pm 0.7 \mathrm{~b}$ & $1.7 \pm 0.5 \mathrm{a}$ & $3.6 \pm 1.0 \mathrm{a}$ & $6.6 \pm 1.6 \mathrm{a}$ \\
\hline & $\begin{array}{l}\mathrm{MeJA}+ \\
5.2 \mathrm{~mm} \mathrm{Se}\end{array}$ & $9.0 \pm 0.3 \mathrm{a}$ & $5.7 \pm 0.6 \mathrm{a}$ & $16.7 \pm 1.1 \mathrm{a}$ & $2.3 \pm 0.01 \mathrm{a}$ & $6.4 \pm 0.3 \mathrm{a}$ & $2.1 \pm 0.4 \mathrm{a}$ & $1.7 \pm 0.3 \mathrm{a}$ & $3.2 \pm 0.5 \mathrm{a}$ \\
\hline
\end{tabular}

${ }^{\mathrm{z}}$ See Table 1.

${ }^{\mathrm{y}} \mathrm{Control}=$ treatment with control solution; MeJA = treatment with $250 \mu \mathrm{M} \mathrm{MeJA}$; MeJA $+5.2 \mathrm{~mm} \mathrm{Se}=$ combination treatment of high level of Se fertilization (5.2 $\mathrm{mM} \mathrm{Na}_{2} \mathrm{SeO}_{4}$ solution) with MeJA spray. Samples were harvested $4 \mathrm{~d}$ after control or MeJA treatment.

${ }^{x}$ Means within each column for each genotype with different letters are significantly different at $P<0.05$, using Fisher's least significant difference analysis. 
MeJA-mediated increases in indolyl and aromatic GSs in floret tissue was a consistent response across the broccoli lines tested in our experiment (Table 3). The combination treatment of both MeJA and high level of Se resulted in a $36 \%$ reduction of total aliphatic GS concentrations compared with the control treatment, but the increase in indolyl GS concentrations in the MeJA treatment compensated for the loss of aliphatic GSs and consequently made total GS levels $4 \%$ and $12 \%$ higher than control and the high level of Se treatment, respectively (Table 3 ). Under the combined treatments, the concentration of glucobrassicin was not significantly increased compared with the control treatments, suggesting that the MeJA-mediated increase in this compound was inhibited under high levels of Se fertilization. The concentrations of neoglucobrassicin significantly increased under the combined treatments but were lower than in the MeJA treatment alone. This result indicates that the increase in neoglucobrassicin concentration mediated by MeJA treatment was also inhibited by high levels of Se fertilization but was less affected than gluconasturtiin and glucobrassicin. Similar to sulforaphane, phenylethyl isothiocyanate derived from gluconasturtiin and $N$-methoxyindole-3-carbinol, the hydrolysis product of neoglucobrassicin, also has human anticarcinogenic bioactivity (Neave et al., 2005; Staack et al., 1998). Our experimental data suggest that the combination treatment of MeJA with Se fertilization may provide beneficial effects for human health promotion through enhanced concentrations of Se and indolyl GSs in broccoli florets.

EFFECT OF SELENIUM FERTILIZATION IN 6-WEEK-OLD BROCCOLI PLANTS. To analyze the effect of Se fertilization on GS concentrations in different tissues and developmental stages of

Table 3. Overall mean glucosinolate (GS) concentration across the five broccoli genotypes treated with control, low levels of selenium (Se), high levels of Se, methyl jasmonate (MeJA), or combination treatment of MeJA with high levels of Se $(n=5)$.

\begin{tabular}{|c|c|c|c|c|c|c|c|c|}
\hline \multirow[b]{3}{*}{ Treatment $^{z}$} & \multirow{2}{*}{$\begin{array}{c}\text { Total aliphatic } \\
\text { GSs }\end{array}$} & \multirow{2}{*}{$\begin{array}{c}\text { Total indolyl } \\
\text { GSs }\end{array}$} & \multirow[b]{2}{*}{ Total GSs } & \multicolumn{2}{|c|}{ Aliphatic $\mathrm{GSs}^{\mathrm{y}}$} & \multirow{2}{*}{$\frac{\text { Aromatic } \mathrm{GS}^{\mathrm{y}}}{\mathrm{GNS}}$} & \multicolumn{2}{|c|}{ Indolyl GSs ${ }^{\mathrm{y}}$} \\
\hline & & & & GRN & GNA & & GBS & NGBS \\
\hline & \multicolumn{8}{|c|}{$\left[\right.$ mean \pm sE $\left(\mu \mathrm{mol} \cdot \mathrm{g}^{-1}\right.$ dry weight $\left.)\right]$} \\
\hline Control & $9.6 \pm 1.5 \mathrm{a}^{\mathrm{x}}$ & $10.0 \pm 4.1 \mathrm{c}$ & $21.6 \pm 5.4 \mathrm{~b}$ & $3.4 \pm 0.3 \mathrm{a}$ & $5.3 \pm 1.2 \mathrm{a}$ & $2.0 \pm 0.6 \mathrm{c}$ & $5.2 \pm 2.0 \mathrm{~b}$ & $4.7 \pm 1.7 \mathrm{c}$ \\
\hline $5.2 \mathrm{~mm} \mathrm{Se}$ & $7.8 \pm 0.9 \mathrm{~b}$ & $9.5 \pm 2.2 \mathrm{c}$ & $19.7 \pm 2.7 b$ & $2.2 \pm 0.4 \mathrm{~b}$ & $5.2 \pm 0.6 \mathrm{a}$ & $2.5 \pm 0.5 \mathrm{~b}$ & $4.5 \pm 1.4 \mathrm{~b}$ & $4.7 \pm 1.6 \mathrm{c}$ \\
\hline MeJA & $9.0 \pm 1.6 \mathrm{ab}$ & $19.6 \pm 4.0 \mathrm{a}$ & $31.9 \pm 5.6 \mathrm{a}$ & $3.3 \pm 0.8 \mathrm{a}$ & $4.9 \pm 1.4 \mathrm{ab}$ & $3.3 \pm 0.7 \mathrm{a}$ & $7.3 \pm 2.2 \mathrm{a}$ & $12.1 \pm 3.5 \mathrm{a}$ \\
\hline $\begin{array}{l}\text { MeJA + } \\
\quad 5.2 \mathrm{~mm} \mathrm{Se}\end{array}$ & $6.2 \pm 1.5 \mathrm{c}$ & $13.8 \pm 4.1 \mathrm{~b}$ & $22.4 \pm 5.4 \mathrm{~b}$ & $1.7 \pm 0.3 \mathrm{~b}$ & $4.0 \pm 1.2 \mathrm{~b}$ & $2.5 \pm 0.6 \mathrm{~b}$ & $4.2 \pm 2.0 \mathrm{~b}$ & $9.4 \pm 3.9 \mathrm{~b}$ \\
\hline
\end{tabular}

${ }^{\mathrm{z} S e e}$ Table 1 .

${ }^{y}$ Control = treatment with control solution; $0.17 \mathrm{~mm} \mathrm{Na}_{2} \mathrm{SeO}_{4}$ solution = low level of Se fertilization; $5.2 \mathrm{~mm} \mathrm{Na}_{2} \mathrm{SeO}_{4}$ solution $=$ high level of Se fertilization; MeJA = treatment with $250 \mu \mathrm{M} \mathrm{MeJA;} \mathrm{MeJA} \mathrm{+} \mathrm{5.2} \mathrm{mM} \mathrm{Se=} \mathrm{combination} \mathrm{treatment} \mathrm{of} \mathrm{high} \mathrm{level} \mathrm{of} \mathrm{Se} \mathrm{fertilization} \mathrm{with} \mathrm{MeJA} \mathrm{spray.}$ Samples were harvested $4 \mathrm{~d}$ after control or MeJA treatment.

${ }^{x}$ Means within each column for each genotype with different letters are significantly different at $P<0.05$, using Fisher's least significant difference analysis.

Table 4. Changes in glucosinolate (GS) concentrations in apical and basal leaves of 6-week-old 'Green Magic' broccoli in controls and plants treated with high levels of selenium (Se) fertilizer, methyl jasmonate (MeJA), and combined treatment of high levels of Se with MeJA treatment $(\mathrm{n}=3)$.

\begin{tabular}{|c|c|c|c|c|c|c|c|c|c|}
\hline \multirow[b]{3}{*}{ Tissues } & \multirow[b]{3}{*}{ Treatment $^{\mathrm{z}}$} & \multirow{2}{*}{$\begin{array}{c}\text { Total } \\
\text { aliphatic } \\
\text { GSs }\end{array}$} & \multirow{2}{*}{$\begin{array}{c}\text { Total } \\
\text { indolyl } \\
\text { GSs }\end{array}$} & \multirow[b]{2}{*}{ Total GSs } & \multicolumn{2}{|c|}{ Aliphatic $\mathrm{GSs}^{\mathrm{y}}$} & \multirow{2}{*}{$\frac{\text { Aromatic GS }}{\text { GNS }}$} & \multicolumn{2}{|c|}{ Indolyl $\mathrm{GSs}^{\mathrm{y}}$} \\
\hline & & & & & GRN & GNA & & GBS & NGBS \\
\hline & & \multicolumn{8}{|c|}{$\left[\right.$ mean \pm se $\left(\mu \mathrm{mol} \cdot \mathrm{g}^{-1}\right.$ dry weight $\left.)\right]$} \\
\hline leaves & $5.2 \mathrm{~mm} \mathrm{Se}$ & $1.31 \pm 0.2 \mathrm{~b}$ & $1.22 \pm 0.04 \mathrm{~b}$ & $3.43 \pm 0.2 \mathrm{~b}$ & $0.28 \pm 0.01 \mathrm{c}$ & $0.28 \pm 0.1$ & $3.9 \pm 0.4 b$ & $0.67 \pm 0.02 \mathrm{bc}$ & $0.53 \pm 0.04 \mathrm{~b}$ \\
\hline & MeJA & $1.38 \pm 0.2 \mathrm{~b}$ & $11.57 \pm 4.7 \mathrm{a}$ & $18.85 \pm 5.1 \mathrm{a}$ & $0.62 \pm 0.1 \mathrm{~b}$ & $\mathrm{ND}^{\mathrm{w}}$ & $0.90 \pm 0.2 \mathrm{~b}$ & $1.19 \pm 0.2 \mathrm{~b}$ & $15.38 \pm 4.6 \mathrm{a}$ \\
\hline & $\begin{array}{l}\mathrm{MeJA}+ \\
\quad 5.2 \mathrm{~mm} \mathrm{Se}\end{array}$ & $0.88 \pm 0.1 \mathrm{~b}$ & $0.85 \pm 0.2 \mathrm{~b}$ & $2.58 \pm 0.3 \mathrm{~b}$ & $0.27 \pm 0.1 \mathrm{c}$ & ND & $0.09 \pm 0.05 \mathrm{~b}$ & $0.13 \pm 0.01 \mathrm{c}$ & $0.72 \pm 0.2 \mathrm{~b}$ \\
\hline \multirow{4}{*}{$\begin{array}{l}\text { Basal } \\
\text { leaves }\end{array}$} & Control & $1.01 \pm 0.2 \mathrm{a}$ & $2.25 \pm 0.2 \mathrm{~b}$ & $4.0 \pm 0.4 \mathrm{~b}$ & $0.36 \pm 0.1 \mathrm{a}$ & $0.35 \pm 0.1 \mathrm{a}$ & $0.73 \pm 0.1 \mathrm{~b}$ & $1.52 \pm 0.1 \mathrm{ab}$ & $0.74 \pm 0.1 \mathrm{~b}$ \\
\hline & $5.2 \mathrm{~mm} \mathrm{Se}$ & $0.79 \pm 0.3 \mathrm{a}$ & $0.83 \pm 0.3 \mathrm{~b}$ & $1.99 \pm 0.8 \mathrm{~b}$ & $0.25 \pm 0.2 \mathrm{a}$ & $0.23 \pm 0.1 \mathrm{a}$ & $0.37 \pm 0.1 \mathrm{a}$ & $0.58 \pm 0.3 \mathrm{bc}$ & $0.22 \pm 0.1 \mathrm{~b}$ \\
\hline & MeJA & $0.51 \pm 0.1 \mathrm{a}$ & $20.33 \pm 2.6 \mathrm{a}$ & $22.07 \pm 2.4 \mathrm{a}$ & $0.12 \pm 0.0 \mathrm{a}$ & $0.07 \pm 0.01 \mathrm{a}$ & $1.23 \pm 0.2 \mathrm{ab}$ & $1.96 \pm 0.5 \mathrm{a}$ & $18.28 \pm 2.8 \mathrm{a}$ \\
\hline & $\begin{array}{l}\text { MeJA + } \\
5.2 \mathrm{~mm} \mathrm{Se}\end{array}$ & $0.71 \pm 0.1 \mathrm{a}$ & $1.62 \pm 0.1 \mathrm{~b}$ & $2.67 \pm 0.2 b$ & $0.25 \pm 0.01 \mathrm{a}$ & $0.16 \pm 0.1 \mathrm{a}$ & $0.34 \pm 0.03 \mathrm{ab}$ & $0.37 \pm 0.03 \mathrm{c}$ & $1.19 \pm 0.1 \mathrm{~b}$ \\
\hline
\end{tabular}

\footnotetext{
${ }^{\mathrm{z}}$ See Table 1.
}

${ }^{\mathrm{y}} \mathrm{Control}=$ treatment with control solution; MeJA = treatment with $250 \mu \mathrm{M} \mathrm{MeJA}$; MeJA $+5.2 \mathrm{~mm} \mathrm{Se}=$ combination treatment of high level of Se fertilization (5.2 $\mathrm{mm} \mathrm{Na}_{2} \mathrm{SeO}_{4}$ solution) with MeJA spray. Samples were harvested $4 \mathrm{~d}$ after control or MeJA treatment.

${ }^{x}$ Means within each column for each tissue with different letters are significantly different at $P<0.05$, using Fisher's least significant difference analysis.

${ }^{\mathrm{w}} \mathrm{ND}=$ not detected . 
broccoli, 6-week-old plants of 'Green Magic' were subjected to the high level of Se fertilization (5.2 $\mathrm{mM} \mathrm{Na}_{2} \mathrm{SeO}_{4}$ ), MeJA treatment $(250 \mu \mathrm{M})$, or the combined treatment. Similar to floret tissues, MeJA alone increased concentrations of indolyl GSs in both apical and basal leaves of 6-week-old broccoli plants (Table 4). Both the high level of Se fertilization and the combined treatment of MeJA with the high level of Se fertilization reduced glucoraphanin and glucobrassicin accumulation in apical leaves of young broccoli plants (Table 4). Total GS concentrations decreased by $63 \%$ and $72 \%$ in apical leaves of seedlings under high Se and the combined treatment, respectively, with $50 \%$ and $33 \%$ reduction of total GSs for the same treatments in basal leaves. The high level of Se fertilization reduced GS accumulation and completely inhibited MeJA-mediated indolyl GS accumulations in 6-week-old broccoli plants. In contrast, floret tissues of the same genotype subjected to higher volumes of $5.2 \mathrm{~mm}$ Se fertilization demonstrated 19\% decrease and 31\% increase, respectively, in total GS concentrations (Tables 1 and 2).

GS profiling data obtained from 6-week-old broccoli plants and florets after Se, MeJA, or the combined treatment provide information to estimate net GS biosynthesis capability in different developmental stages of plants responding to limited sulfur or sulfur-containing amino acid availability caused by the competition between sulfur and Se uptake and assimilation. The different response between young plant leaf tissues and florets from mature plants may be the result of the differences in size of available pools of GS precursors and sulfur required for de novo GS biosynthesis. Increased accumulation of indolyl GSs in floret tissues in the combined treatment may be from translocation of GSs or GS precursors from sink tissues such as leaves, roots, or stems to the florets.

Sulfur AND SELENIUM CONCENTRATIONS. The total sulfur concentrations determined in florets and basal leaves of 6week-old plants after high level of Se fertilization, MeJA treatment, or combination treatment are shown in Figure 2. High levels of Se fertilization and the combined treatment did not cause any significant changes in sulfur concentrations in the florets of 'Green Magic' and 'Sultan', whereas the same treatments decreased sulfur concentration by $36 \%$ and $33 \%$, respectively, compared with the control treatment in basal leaves of 'Green Magic' 6-week-old plants, suggesting competitive inhibition of sulfur uptake under high levels of Se fertilization. Se and sulfur are absorbed by plants through their roots. Because both Se and sulfur belong to Group VI of the periodic table and have similar chemical properties, uptake and assimilation of Se and sulfur are influenced by competitive interactions (reviewed in Sors et al., 2005). Our result is not consistent with previous reports in which it was observed that Se fertilization increased sulfur content in leaf tissue of rapid-cycling B. oleracea (Charron et al., 2001; Toler et al., 2007). In our experiment, young broccoli plants were exposed to a relatively higher concentration of $\mathrm{Se}$ (5.2 $\mathrm{mM} \mathrm{Na}_{2} \mathrm{SeO}_{4}$ ). This fertilization condition resulted in an increase in Se concentration in basal leaves of small plants ranging from 1.5 (control) to $1454 \mu \mathrm{g} \cdot \mathrm{g}^{-1}$ dry weight (high level of Se fertilization). This level of Se was much greater than that found in florets of the same genotype, which ranged from 13.0 (control) to $576 \mu \mathrm{g} \cdot \mathrm{g}^{-1}$ (high level of Se fertilization) (Fig. 2B). Greater accumulation of Se in young plant tissues may result in the competitive interaction effect between Se and sulfur in our experiment. Six-week-old broccoli plants grown under the high 
Table 5. Percentages of total phenotypic variation in glucosinolate (GS) concentrations associated with genotype, treatment, and genotype-bytreatment interaction for the floret tissues of five broccoli genotypes treated with control, $250 \mu \mathrm{M}$ methyl jasmonate (MeJA), high level of selenium (Se) (5.2 mM Na $2 \mathrm{SeO}_{4}$ ), or combination of high level of Se with MeJA treatment.

\begin{tabular}{|c|c|c|c|c|c|c|c|c|}
\hline \multirow[b]{2}{*}{ Source of variation } & \multirow{2}{*}{$\begin{array}{c}\text { Total aliphatic } \\
\text { GSs }\end{array}$} & \multirow{2}{*}{$\begin{array}{l}\text { Total indolyl } \\
\text { GSs }\end{array}$} & \multirow[b]{2}{*}{ Total GSs } & \multicolumn{2}{|c|}{ Aliphatic GSs ${ }^{z}$} & \multirow{2}{*}{$\frac{\text { Aromatic } \mathrm{GS}^{\mathrm{z}}}{\mathrm{GNS}}$} & \multicolumn{2}{|c|}{ Indolyl GSs ${ }^{z}$} \\
\hline & & & & GRN & GNA & & GBS & NGBS \\
\hline Genotype & $0.0^{*}$ & $62.4 * * *$ & $69.2 * * *$ & $23.7 * * *$ & $9.1 * * *$ & $63.5^{* * *}$ & $70.0^{* * *}$ & $54.5 * * *$ \\
\hline Treatment (Se) & $8.6^{* *}$ & 0.0 & 1.0 & $18.3^{* * *}$ & 0.0 & $7.9 * *$ & 0.0 & 0.0 \\
\hline Residual & 46.7 & 20.8 & 27.4 & 25.1 & 24.2 & 23.9 & 20.6 & 24.5 \\
\hline Genotype & $54.3 * * *$ & $33.0 * * *$ & $42.7 * * *$ & $51.1 * * *$ & $70.0^{* * *}$ & $40.7 * * *$ & $49.9 * * *$ & $31.0 * * *$ \\
\hline $\mathrm{G} \times \mathrm{T}$ & 0.0 & 0.0 & 0.0 & 10.8 & 4.3 & 1.2 & $30.2 * * *$ & $7.8^{*}$ \\
\hline Residual & 45.0 & 19.7 & 22.8 & 31.8 & 24.2 & 22.2 & 14.2 & 18.5 \\
\hline Genotype & 0.0 & $52.3 * * *$ & $47.2 * * *$ & $4.2 * * *$ & $0.0 * * *$ & $44.8 * * *$ & $40.2 * * *$ & $48.1 * * *$ \\
\hline Treatment (Se and MeJA) & $27.1 * * *$ & $6.2 * * *$ & 0.0 & $36.8 * * *$ & $0.0 * * *$ & $0.0 * *$ & 0.0 & $15.5^{* * *}$ \\
\hline $\mathrm{G} \times \mathrm{T}$ & $52.2 * * *$ & $25.2 * * *$ & $31.8 * * *$ & $46.4 * * *$ & $81.7 * * *$ & 29.0 & $31.6 * * *$ & 27.9 \\
\hline
\end{tabular}

${ }^{\mathrm{z}}$ See Table 1.

${ }^{\mathrm{y}} \mathrm{G} \times \mathrm{T}=$ genotype $\times$ treatment interaction.

$*, * *, * * *$ Significant at $P<0.1,0.05$, or 0.01 , respectively.

level of Se fertilization also showed inhibited growth compared with controls, whereas florets of mature broccoli plants did not display any observable differences between treatments in our experiment (data not shown). Further study is required to elucidate the effect of Se fertilization on sulfur uptake in 6-week-old broccoli plants by treating them with a range of Se concentrations. Variations in activities of key enzymes such as adenosine 5 '-phosphosulfate reductase associated with sulfur assimilation also needs to be measured in different types of broccoli tissues to analyze its relationship with Se accumulation (Sors et al., 2005).

The Se concentration determined in the basal leaves of 6-weekold plants and florets of 'Green Magic' did not show significant differences between the high level of Se fertilization and the combination treatment of MeJA and the high level of Se fertilization, indicating no interaction between treatments. However, the Se levels detected in florets of 'Sultan' displayed significant differences $(P<0.05)$ in Se concentration between the high level of Se fertilization and combination treatment of Se with MeJA (Fig. 2B).

GeNOTYPE AND TREATMENT VARIATION. Analysis of variance was applied to partition the total phenotypic variation for GS concentration into components associated with the genotype, treatment, and $\mathrm{G} \times \mathrm{T}$ interaction (Table 5). Percentage of the total variation for aliphatic and indolyl GS concentrations varied depending on different treatments. In the high level of Se fertilization, most of the variation in indolyl GSs was described by the genotypic effects ranging from $54.5 \%$ to $70.0 \%$, whereas the variation of total aliphatic GSs was primarily associated with the Se treatment and genotype $\times$ Se treatment interactions $(8.6 \%$ and $41.7 \%$, respectively). In contrast, the genotypic effects described most variation for total aliphatic GSs (54.3\%) in the MeJA treatment, in which the total indolyl GSs variability was primarily attributed to the MeJA treatment effect (47.3\%). The combined treatment of high levels of Se with MeJA increased the percentage of variation caused by $\mathrm{G} \times \mathrm{T}$ interactions in nearly all classes of GSs significantly, suggesting that the combined treatment impacts on the stability of both aliphatic and indolyl GS concentrations among individual genotypes.
The existence of substantial variability in GS concentrations attributed to differences in the genotype across different treatments suggests that genetic manipulation can be conducted to increase GS concentrations under Se fertilization, MeJA, or combined treatments. The high proportion of the phenotypic variation for aliphatic GSs was primarily contributed by the genotype $\times$ Se treatment interaction, indicating that selection and breeding of cultivars can be performed to optimize Se uptake. In a breeding program to develop broccoli with enhanced health promotion, attention should be given toward identifying germplasm in which GS biosynthesis (particularly glucoraphanin) is not as sensitive to Se fertilization and uptake. Further studies need to be conducted in the field to validate our observations.

\section{Literature Cited}

Bodnaryk, R.P. 1994. Potent effect of jasmonates in indole glucosinolates in oilseed rape and mustard. Phytochemistry 35:301-305.

Brown, A.F., G.G. Yousef, E.H. Jeffery, B.P. Klein, M.A. Wallig, M.M. Kushad, and J.A. Juvik. 2002. Glucosinolate profiles in broccoli: Variation in levels and implications in breeding for cancer chemoprotection. J. Amer. Soc. Hort. Sci. 127:807-813.

Charron, C.S., D.A. Kopsell, W.M. Randle, and C.E. Sams. 2001. Sodium selenate fertilization increases selenium accumulation and decreases glucosinolate concentration in rapid-cycling Brassica oleracea. J. Sci. Food Agr. 81:962-966.

Clark, L.C., G.F. Combs, B.W. Turnbull, E.H. Slate, D.K. Chalker, J. Chow, L.S. Davis, R.A. Glover, G.F. Graham, E.G. Gross, A. Krongrad, J.L. Lesher, H.K. Park, B.B. Sanders, C.L. Smith, and J.R. Taylor. 1996. Effects of selenium supplementation for cancer prevention in patients with carcinoma of the skin. J. Amer. Medical Assn. 276:1957-1963.

Davis, C.D., H. Zeng, and J.W. Finley. 2002. Selenium-enriched broccoli decreases intestinal tumorigenesis in multiple intestinal neoplasia mice. J. Nutr. 132:307-309.

Finley, J.W., C.D. Davis, and Y. Feng. 2000. Selenium from high selenium broccoli protects rats from colon cancer. J. Nutr. 130:2384-2389.

Finley, J.W., C. Ip, D.J. Lisk, C.D. Davis, K.J. Hintze, and P.D. Whanger. 2001. Cancer-protective properties of high-selenium broccoli. J. Agr. Food Chem. 49:2679-2683. 
Finley, J.W., A.S. Keck, R.J. Robbins, and K.J. Hintze. 2005. Selenium enrichment of broccoli: Interaction between selenium and secondary plant compounds. J. Nutr. 135:1236-1238.

Halkier, B.A. and J. Gershenzon. 2006. Biology and biochemistry of glucosinolates. Annu. Rev. Plant Biol. 57:303-333.

Keck, A.S. and J.W. Finley. 2006. Aqueous extracts of seleniumfertilized broccoli increase selenoprotein activity and inhibit DNA single-strand breaks, but decrease the activity of quinine reductase in Hepa 1c1c7 cells. Food Chem. Toxicol. 44:695-703.

Linsinger, T., N. Kristiansen, N. Beloufa, H. Schimmel, and J. Pauwels. BCR information; Reference materials; EUR 19764 EN; European Commission, 2001. 15 May 2011. <http://www.irmm.jrc. be/html/reference_materials_catalogue/catalogue/attachements/ BCR-190r_report.pdf>.

Liu, A.G., S.E. Volker, E.H. Jeffery, and J.W. Erdman. 2009. Feeding tomato and broccoli powders enriched with bioactives improves bioactivity markers in rats. J. Agr. Food Chem. 57:7304-7310.

Neave, A.S., S.M. Sarup, M. Seidelin, F. Duus, and O. Vang. 2005. Characterization of the N-methoxyindole-3-carbinol (NI3C)-induced cell cycle arrest in human colon cancer cell lines. Toxicol. Sci. 83:126-135.

Pedrero, Z., Y. Madrid, H. Hartikainen, and C. Camara. 2008. Protective effect of selenium in brócoli (Brassica oleracea) plants subjected to cadmium exposure. J. Agr. Food Chem. 56:266-271.

Rausch, T. and A. Wachter. 2005. Sulfur metabolism: A versatile platform for launching defence operations. Trends Plant Sci. 10:503-509.

Rayman, M.P. 2004. The use of high-selenium yeast to raise selenium status: How does it measure up? Brit. J. Nutr. 92:557-573.

Robbins, R.J., A.S. Keck, G. Banuelos, and J.W. Finley. 2005. Cultivation conditions and selenium fertilization alter the phenolic profile, glucosinolate, and sulforaphane content of broccoli. J. Med. Food 8:204-214.

Sah, R.N. and R.O. Miller. 1992. Spontaneous reaction for acid dissolution of biological tissues in cloased vessels. Anal. Chem. 64:230-233.
Schonhof, I., H.P. Klaring, A. Krunmbein, and M. Schreiner. 2006. Interaction between atmospheric $\mathrm{CO}_{2}$ and glucosinolates in broccoli. J. Chem. Ecol. 33:105-114.

Sors, T.G., D.R. Ellis, and D.E. Salt. 2005. Selenium uptake, translocation, assimilation and metabolic fate in plants. Photosynth. Res. 86:373-389.

Staack, R., S. Kingston, M.A. Wallig, and E.H. Jeffery. 1998. A comparison of the individual and collective effects of four glucosinolate breakdown products from Brussels sprouts on induction of detoxification enzymes. Toxicol. Appl. Pharmacol. 149:17-23.

Sugihara, S., M. Kondo, Y. Chihara, M. Yuji, H. Hattori, and M. Yoshida. 2004. Preparation of selenium-enriched sprouts and identification if their selenium species by high-performance liquid chromatography-inductively coupled plasma mass spectrometry. Biosci. Biotechnol. Biochem. 68:193-199.

Talalay, P. and J.W. Fahey. 2001. Phytochemicals from cruciferous plants protect against cancer by modulating carcinogen metabolism. J. Nutr. 131:3027S-3033S.

Toler, H.D., C.S. Charron, and C.E. Sams. 2007. Selenium increases sulfur uptake and regulates glucosinolate metabolism in rapidcycling Brassica oleracea. J. Amer. Soc. Hort. Sci. 132:14-19.

Tracy, M.L. and G. Moeller. 1990. Continuous flow vapor generation for inductively coupled argon plasma spectrometric analysis. Part I. Selenium. J. Assn. Offic. Anal. Chem. 73:404-410.

van Dam, N.M., L. Witjes, and A. Svatos. 2003. Interaction of between aboveground and belowground induction of glucosinolates in two wild Brassica species. New Phytol. 161:801-810.

Wathelet, J.-P., R. Iori, N. Mabon, S. Palmieri, O. Leoni, P. Rollin, and M. Marlier. 2001. Determination of the response factors of several desulfo-glucosinolates used for quantitative analysis of Brassicaceae. 15 May 2011. <http://hdl.handle.net/2268/40821>.

White, P.J. and M.R. Broadley. 2005. Biofortifying crops with essential mineral elements. Trends Plant Sci. 10:586-593. 